\title{
Psycholinguistic Preconditions of Gradation Functioning in the Individual World Picture
}

\section{Психолінгвістичні передумови функціювання градації в індивідуальній картині світу}

\author{
Liudmyla Marchuk \\ Doctor in Philology, \\ Professor \\ Oleh Rarytskyi \\ Doctor in Philology, \\ Professor \\ Kamianets-Podilskyi Ivan Ihiienko \\ National University \\ $\triangle 61$, Ivan Ohiienko \\ Str., Kamianets-Podilskyi, \\ Khmelnytskyi Reg., \\ Ukraine, 32300
}

\author{
Людмила Марчук \\ доктор філологічних наук, \\ професор
}

E-mail: 1yudmylamarchuk60@gmail.com orcid.org/0000-0002-9022-2103

Олег Рарицький доктор філологічних наук, професор

\author{
E-mail: rarytskyi_o@ukr.net \\ orcid.org/0000-0003-1941-584X \\ Кам'янеиь-Подільський \\ національний університет \\ імені Івана Огієнка \\ $\triangle$ вул. Івана Огієнка, 61, \\ Кам'янець-Подільський, \\ Хмельницька обл., Україна, 32300 \\ Original manuscript received August 05, 2018 \\ Revised manuscript accepted September 24, 2019
}

\section{ABSTRACT}

Aim of the research. To describe objective and subjective factors of language semantic interpretation of gradation thinking content (psychological and linguistic aspects in gradation semantics). 
Research methods. The article describes the foundations of distinguishing functional and semantic gradation category in the Ukrainian language which is reflected in the units of different levels. The linguistic cognitive character of the investigation is proved within these notions, as one of the principle tasks of the work is to determine mental anthropocentric and psychological factors of emerging gradation utterances in the Ukrainian language, which demonstrate the unity of linguistics and psychology, language and speech. The methodology consisted in comparing the materials of gradation in different levels, carrying out hypothetic modeling of the gradation scale on the basis of functioning gradation verbal markers, determining psychological foundations for gradation functioning in the individual picture of the world. The interaction of the objective (conceptual world of the gradated $O$ ) and the subjective (emotional and intellectual sphere of the gradator S) worlds creates the gradation fragment in a language, its orientation concerning the gradation dimension $(\mathrm{O}-$ object, $S$ - subject of gradation).

Results. The investigation of the motivation, semantic accentuation and communicators character, i.e. the inner world of the speaker and listener, text author and reader, enabled to code and decode the information given in the text. For decoding we identified the gradation units and explicated them on the sentence (text) level, distinguished pragmatic structures with redundant information. Thus the problem of certain stereotypes as the norm of environment perception, deviations from the norm was partially solved and the possibilities of reconstructing the quality characteristics of the language world picture were expanded.

Conclusion. The choice of the verbal implementation for gradation category is carried out by the author of the communication act, it is subordinated to particular psychological regularities, which are general for human language but mentally individual concerning the communicator personality and individual language picture of the world.

Key words: gradation category, gradation lexeme, introvert, extravert, personology, implication.

\section{Вступ}

Актуальність дослідження зумовлена потребою систематизації лексичних і граматичних засобів вираження градації у функційному плані, ураховуючи прагматичний характер градаційних висловлень в українській мові. Дослідження градації в семантичному, когнітивному та функційному аспектах відповідає сформованим сучасним категорійним підходам до вивчення мовних явищ, оскільки поєднує параметри як традиційної, так i нової лінгвістичної парадигми. 
Психолінгвістичні передумови функиіювання градаціï..

Мета дослідження - дослідити об'єктивні та суб'єктивні чинники мовної семантичної інтерпретації мисленнєвого змісту градації (психологічний i лінгвістичний аспекти в семантиці градаціï).

\section{Методи дослідження}

Відповідно до мети та завдань дослідження в роботі застосовано методи: градаційного шкалювання, граматичного, семного і комплексного аналізу тексту, індивідуального моделювання висловлення.

Поняття градаційної шкали дотичне до поняття психолінгвістичної шкали, якою на матеріалі європейських мов послуговуються вчені для визначення параметрів оцінки висловлення. Репрезентований метод градаційного шкалювання в рамках когнітивної лінгвістики $€$ актуальним, оскільки дає можливість визначити загальні закони градації, властиві носієві конкретної мови (семантичному суб'єкту); порівнювати мовні одиниці за градаційним критерієм; використовувати статистичні процедури та семантичні оцінки довкілля.

Використано матеріали опису асоціативного сприйняття довкілля через накладання градаційної сітки на авторську мовну картину світу.

\section{Результати дослідження}

Факти мови завжди відбивають класи понять і суджень, у яких ядерні елементи, що допускають логічне визначення, мають невизнані динамічні й емоційні показники. Одні 3 них мають простішу будову, інші - логічно статичне поняття плюс динамічний зміст. Напр.: «Поступова зміна пейзажів південнонімецьких у північноіталійські була для мене значно вагомішим свідченням подорожі, ніжс прикордонний контроль, якого практично не було. Адже за якісь дві-три години таки відбувся переїзд в іншу культуру» (Андрухович, 1999: 39). «Вони й з досвітків приходили вчасно, не догулювали до ранку, як інші парубки» (Мушкетик, 2003: 18). 
Градаційна особиста сітка сприйняття навколишнього світу, яка накладається автором на текст, може передаватися як через підвищення, так і через спад логічного й емоційного. Напр.: 1) «Найбільшим гріхом, найглибшим тавром на шкірі Бу-Ба-Бу завжди залишатиметься наша спроба розтопити цюю брилу пісної недовченої поважності на всьому українському» (Андрухович, 1999: 84) (висхідна градація); 2) «Література - Храм!»-хамаркнув мені якось один розгніваний письменник. Нічого не заперечую проти храму. Хоча з такою ж часткою істини можна стверджувати: «Література - ие Лікарня! Література - ие икола! Література изе Фабрика! Література - изе Вокзал! Література - изе Пароплав! Це Бордель! Це Смітник! Це Нужниик!» (Андрухович, 1999: 8) (спадна градація, спад емоційної оцінки).

Створюючи збалансованість, виводимо логічно рівне, нульовий ступінь, від якого можливе наростання/спадання градаційної ознаки. Напр.: «Коли маєш до диспозицї Ніщчо, себто голу рівнину, по якій - скачи хоч десять тижнів - нічого не зміниться, починаєш вірувати у марноту марнот, в нікчемність усіх зусиль, у повну людську неспроможність» (Андрухович, 1999: 37).

Вербальна комунікація не вільна від мотивів, потреб та емоцій iï суб'єктів - можливі ситуації, у яких емоційно-вольові параметри сприйняття й узагальнення можуть збігатися, виникає «зв'язок породження смислу з проблемою активності суб' єкта» (Журавлев \& Журавлева, 2017: 48). Проявляються нові конфігурації градації, які вказують на збільшення або зменшення позитивної чи негативної енергії, напр.: «Ще він любив, як сонячне проміння падало в чашку з чаєм: тоді колір такий насичений ставав, такий міцний - од самого погляду на нього терпло в роті» (Таран, 2007: 132).

Отже, емоційне значення градаційної лексеми увиразнено системою семантичних відношень між мовними одиницями градаційного висловлення, яке репрезентує свою функційну рухливість. Тобто, як реальну лексико-семантичну одиницю, слово зі значенням градації подано у всіх виявах і зв'язках, а, як одиницю функційну, схарактеризовано суб'єктивно невичерпними можливостями власної віртуальної реалізації в живому мовленні, що $є$ запорукою розвитку системи мови. Напр.: «Ця «Книга Проповідника, сина Давидового, ияаря в Єрусалимі» така сама правдива сьогодні, при нашій рептильній Верховній Раді, як була 
прадива в часи «сина Давидового», як була правдива ще задовго до його часів, як буде правдива в усі грядущі часи. Справді, багато печалі в цій мудрості, $і$ чим більше мудрості - тим більше печалі: буття людства, його історія - цее, може, не така вже й «оптимістична трагедія", як хотілося б, $i$, даючи уроки, вона водночас наче й не дає уроків, $і$ ота ї̈ «оптимістичність» - таки трагедійна $і$ бути іншою не може» (Гуцало, 2007: 13).

Двокомпонентна структура емоцій підкреслена в багатьох концепціях, у тому числі й психологічних. Особливо вона пов'язана 3 теорією особистості (Хьелл \& Зиглер, 2000: 31). Дослідники зазначають, що суттєвим психолінгвальним маркером спотворення інформації, а в нашому випадку накладання певних емоцій через уживання градаційних структур, $є$ низький ступінь когнітивної складності тексту (Засєкін \& Розенгарт, 2018: 98). Провідним психолінгвістичним маркером градаційної інформації та способом iii представлення залишається індивід, людина 3 певним типом особистості, яка схильна до виявлення звичайних або нормованих почуттів, або до їхнього перебільшення чи применшення, а, отже, відображення цих емоцій в експресивних градаційних лексемах чи цілих текстах (Марчук, 2007). Тоді градаційні вияви можна розуміти як засіб раціоналізації процесу пізнання, а особливо тих властивостей, які дозволяють знайти спосіб структурування буття, в межах якого відбувається селекція градаційних та оцінних характеристик, серед яких виділяється норма - середнє на шкалі градації, що додає в репрезентований процес особливу абстрактну умову - інтеграл градаційного інформаційного наповнення.

У романі Віктора Баранова «Смерть по-білому» автор через героїв створює власну картину світу з усією гамою почуттів: гнів, смуток, радість, тривога тощо. Наприклад, головний герой роману відчуває спокій, сидячи перед запаленим каміном: «Я просто відпочивав тілом і душею, переконуючи себе в тому, щзо викликане мною до нетривалого життя полум'я спопеляє мою втому, стреси, чорну енергетику, які призбируються упродовж буднів, у кожному 3 нас, навіть коли ми того й не помічаємо» (Баранов, 2013: 10). Спокій, або нормальний стан особистості передано через процес знищення негативних емоцій. Стрес описано в ситуації, коли до головного героя приходить майстер камінів, якого, за чутками, поховали: «Отут настало те, щэо теперішні молоді та безвусі 
називають «повний аут» (ну, цуе найнебезневинніший переклад 3 їхнього жаргону) (Баранов, 2013: 15). Повний аут - це визначення найвищої межі емоційних відчуттів - стан афекту. Такий контекст властивий, наприклад, текстам шістдесятників (Рарицький, 2018).

На опис істеричного нападу, а, отже, віддзеркалення певного типу особи - інтроверта невротичного - натрапляємо у такому тексті: «Ревище стояло на півсвіту. Ніхто не знав, чим скінчиться цеей день; міг би й каретою «ивидкої допомоги» та гамівною сорочкою. Якби не батько. Я доплакувала-дохлипувала у його заспокійливих обіймах» (Баранов, 2013: 65).

У побудовах - чи то антонімічні пари з гранично вираженими оцінками, чи предикати, що відображають почуття людини, чи сполуки 3 інтенсифікаторами дуже, чи назви героїв - ми бачимо відображення світу через вищий ступінь його градації, оскільки герой перебуває у стані афекту 3 певним вираженням почуттів. Підкреслює цей стан й іменник з суфіксом збільшеності (ревище), i редуплікаційна сполука доплакувала-дохлипувала. Саме когнітивний напрямок у персонології підкреслює вплив інтелектуальних чи мисленнєвих процесів на стан людини.

Один із дослідників гуманістичного напрямку в теорії особистості Абрахам Маслоу (Maslow, 1971: 724-725) стверджував, що існують вершинні переживання, тобто переживання моменту благоговійного трепету, захоплення i екстазу. Ці почуття можна відобразити на «шкалі вершинних переживань» (Maslow, 1971: 92-108). Отже, з погляду психології, відображення градаційної ознаки виникає як унаслідок впливу середовища, так i за рахунок психологічного типу автора чи зображуваного героя. Концепція оцінного процесу передбачає, що це скрупульозний неперервний розгляд досвіду та розміщення в рамках цього досвіду цінностей у певному порядку відповідно до їхньої здатності задовольняти потреби, пов'язані 3 тенденцією актуалізації. Наприклад: «... втішаємося тим, щуо то є велике щцастя для людини - не знати власного майбутнього. Щастя невідання, вготованого нам долею, - конкретна, дана нам у почуттях (саме в почуттях!) реальність. А все, щзо ми бачимо й відчуваємо в так званому реальному житті, в кожній так званій реальній ситуації, - міраж, марево, видиво, яке минає $i$ відходить у небуття» (Баранов, 2013: 110). 
Психолінгвістичні передумови функиіювання градацุï̈..

Тип поведінки має також соціальний характер. Людина, що займає певний статусний щабель у суспільстві, може дозволити собі (свідомо!) різний тип поведінки, яку можна оцінити як негативну або позитивну 3 найвищою мірою вияву. Напр.: «Його дуже вразила поведінка військових. Не раз він приходив додому й жалівся доньиі на їхні нахабство $i$ грубість. Поранені чи травмовані червоноармійці (здебільшого після пиятики) не зважали ні на кого, поводилися по-хамськи, обзивали медперсонал часто-густо такими словами, яких він і не чув ніколи в житті. Лікаря Микитчука, який керував лікарнею, вигнали в перші ж дні. Могло бути значно гірше. Урятувало його те, шчо розміняв сьомий десяток. Потім з'явився якийсь капітан, котрий не мав жодного стосунку до медицини $i$ з изєї царини близько був знайомий тільки з формулою С2H5OH. Він любив скаржитися, як важко «руководить этим бардаком» (Цінцірук, 2017: 76) (описано період 1939 року, Львів), поведінку червоноармійців, які заполонили Львів, передано лексемами нахабство, грубість, поводитися по-хамськи, це й створює картину хаосу з яскраво вираженою авторською негативною оцінкою щодо подій 1939 року.

О.М. Вольф (2002) наголошувала на поєднанні двох станів емоційного і ментального у процесі передання оцінної інформації. Однією з основних характеристик предикатів $є$ різна інтенсивність та їхня здатність до інтенсифікації. Тому семантика градації виявляється як експліцитно, так й імпліцитно. Експлікація притаманна власне градаційним висловленням, метою яких є віддзеркалення ступеня повноти ознаки. Градаційним висловленням властиве комплексне використання експліцитних засобів: суфіксів суб'єктивної оцінки, компаративів, суперлативів, елативів, предикатів більше, ніж/менше, ніж, градаційних речень. Напр.: «Однак, якщо ие був безлад, то не менш довериений, ніжк баварський лад» (Андрухович, 1999: 139); «Розпалена жагою публіка на дев'ять десятих складалася з таких, котрі жодного разу в опері не бували, більше того, - жодної опери не чули, а про мещцо-сопрано мали уявлення не більще, ніж про модерато кантабіле» (Андрухович, 1999: 92).

Інтенсивність градації з погляду емотивної функції досить часто пов'язана $з$ порушенням стереотипної поведінки індивіда в широкому діапазоні - від фізичних дій до ментальних станів. Напр.: «У нього, щэо намагався мати нерви, наче ияяхи, а почуття, як 
Psycholinguistic Preconditions of Gradation Functioning...

метереологічні вловлювання пророцтва, несподівано так задощиили очі» (Процюк, 2004: 57); «така гостра праісторична тиша висить над твойм містом, Микито... Тобі так душно і парко» (Процюк, 2004: 93).

Аналіз мовної семантики градації - ii специфічних, нематематичних, приблизно-оцінних форм вимагає уваги до людського чинника: суб'єкта та адресата 3 їхнім фондом знань, соціальною, груповою й індивідуальною психологією пізнання й діяльності, які певним чином віддзеркалюють градаційні відношення буття через загальнонаукові факти. Особливості людської свідомості 3 ii інтелектуальною та емоційно-вольовою сферами, з одного боку, та нерівномірний розподіл знань між індивідами - 3 іншого, створюють як передумови для комунікації взагалі (Кацнельсон, 1972: 114), так і власне мовні особливості категорійних змістових одиниць мови / мовлення, або, іншими словами, мовних понять, якими оперують суб'єкти мовленнєвого спілкування.

Таким чином, такий огляд психолінгвістичних основ для бази градаційних висловлень використовується в психолінгвістиці, когнітивній лінгвістиці, в тому числі й у корпусі текстів, наприклад, в процесі семантичного опрацювання тексту (Turney \& Pantel, 2010). Автори сучасних досліджень приходять до висновку, що в епоху нових наукових парадигм ці методи змінюють уявлення про безпосередній мисленнєводослідницький процес (Keuleers \& Balota, 2015: 1458).

Структуруванням людського знання, яке лежить в основі мовної комунікації, активно займається когнітивна психологія, психолінгвістика й когнітивістика. На окремі теоретичні передумови вияву когнітивних структур мови/мовлення вказував Л.С. Виготський. Наприклад, слова «багато» i «мало», «більше» i «менше», «великий» i «маленький» $є$ термінами приблизної, неаналітичної, емпірично усвідомленої кількості. Їхні значення відображають глобальні, не уточнені приблизно-оцінні поняття чи - за Л.С. Виготським - «змістові комплекси» (Выготский, 1982: 162-168).

Багатий матеріал щодо виділення когнітивно-психологічних механізмів градації, особливо - ii приблизно-оцінних форм, дає праця Ж. Піаже «Генеза числа у дитини» (Пиаже, 1969: 233-565). Ж. Піаже експериментальним шляхом дійшов висновку, що на ранніх 
стадіях інтелектуального розвитку індивіда поняття числа у нього відсутнє, а «величина зводиться... до конкретних асиметричних відношень між властивостями, тобто до порівнянь з використанням термінів «більше» чи «менше»... Але ці відношення залишаються перцептивними (Пиаже, 1969: 246). Враховуючи той факт, що мовні форми «більше» й «менше» не специфічні для дитячого мовлення, уважаємо, що в основі аналогічних висловлювань дорослих комунікантів можуть лежати такі ж елементарні мисленнєві (перцептивні) операції. Пор.: у Л.С. Виготського: «хоча мисленню дорослої людини доступно утворення понять та оперування ними, проте не все воно заповнено цими операціями» (Выготский, 1982: 168). I якщо допустити, що слова «більше» й «менше» виражають наглядні поняття чи псевдо поняття, то i на них може розповсюджуватися твердження: «У псевдо поняттях надзвичайно часто й відбувається мислення в нашому звичайному житті» (Выготский, 1982: 168).

Слова «багато», «мало», «однаково» передають, на думку Ж. Піаже, кількісну оцінку, що має опертям глобальне порівняння перцептивної наглядності на рівні неаналітичної «брутто-величини» або «величини без одиниць» (Пиаже, 1969: 322-323). Якщо подивитися на цю проблему як на таку, яка визначає об'єкти буття, то таку оцінку можна визначити як градаційну вербальну, яка передає адекватне сприйняття об’єктів чи поведінки суб’єктів. Наприклад, оцінка групи юнаків працівником поліції: «Такі, коли нападають на когось усі гуртом, менш за все дбають про те, аби ненароком не вбити людину» (Кокотюха, 2006: 60).

Ж. Піаже доводить, що для всіх приблизно-оцінних когнітивних комплексів важливе опертя на порівняння, в основі якого може лежати синкретне зорове сприйняття довкілля, тимчасові відмінності, наприклад, у довготі окремих дій тощо (Пиаже, 1969: 276-284). Пор.: «У воді щуось хлюпнуло. Судячи зі звуку, десь плавала справді велика рибина. А може, щуе щзось більше, про щ⿻ можна тільки здогадуватися» (Кокотюха, 2006: 259). Тобто, на безпосередній процес сприйняття довкілля через певну градаційну сітку та відтворення закодованої інформації лексемами впливає, крім зазначених чинників, досвід людини, сенсорне сприйняття зовнішніх подразників (Andrews, Vigliocco \& Vinson, 2009), 
лексичний запас, здатність суб'єкта сприймати складні лексичні рішення (Juhasz, Lai \& Woodcock, 2015).

Опираючись на вчення Л.С. Виготського та погоджуючись 3 тим, що «будь-яке нове слово 3'являється на підставі виділення однієї якої-небудь ознаки, яка впадає в очі» (Выготский, 1982: 174), можна уточнити мисленнєвий зміст приблизної градаційної оцінки, а саме: стверджуємо, що іiі мовленнєвомисленнєві механізми діють не на рівні оперування науково-теоретичними знаннями, а на рівні конкретних комплексів ознак, які формуються при безпосередньому зоровому, слуховому, сенсорному сприйнятті реальних величинвідмінностей.

В.Ф. Петренко визначає одну з можливих форм відображення світу в свідомості як предметного образу - одиниці перцептивної стадії психіки, одиниці сприйняття, що є сукупністю чуттєвих ознак об’єкта, які дають можливість зберегти у свідомості такі інваріанти об'єкта як форму, віддаленість від суб'єкта, параметри його руху тощо (Петренко, 1988: 7).

Також репрезентація довкілля через образ залежить від мотиваційної сфери та емоційного стану суб'єкта. На вербальну комунікацію впливають потреби й емоції іiі суб'єктів, тому можливі випадки, в яких емоційно-вольові параметри сприйняття й спілкування можуть співпадати, у людини під впливом мотиваційного чинника порушуватимуться константи сприйняття й людина може завищувати (чи зменшувати) якийсь об'єкт/суб'єкт, його розмір тощо залежно від його значимості, соціального статусу. Таким чином, людина передає власне розуміння чи нерозуміння довкілля.

Отже, в художньому тексті як нематематичній, приблизнооцінній, вербальній мовній градації можливість модифікації змісту під впливом мотиваційних потреб та емоційних чинників $є$ однією 3 релевантних ознак, яка відбиває діалектику суб'єктивного й об'єктивного. Градація є складною системою, яка переплітається 3 категорією оцінки, інтенсивності та іншими дотичними до психолінгвістики категоріями, які мають як спільні, так і відмінні ознаки, що сприяє «виникненню значень різних мовних одиниць і концептуальних конструкцій» (Neuman, Neuman \& Cohen, 2017).

Імплікаційна градація характерна для градаційно-оцінних висловлень, у яких віддзеркалені градаційні опозиції, пор.: 
Психолінгвістичні передумови функиіювання градайї...

«Коли прийняти версію геніальності як чогось середнього між непорозумінням $i$ випадковістю, то тут присутня саме вона, геніальність» (Андрухович, 1999: 116).

Психологічна градація грунтується на асоціативних зв'язках, тобто не має прямого матеріального вияву. Можна виділити кілька типів психологічної градації.

1. Градація з експліцитними й імпліцитними засобами. Напр.: «Довкола ріденький, але більш, ніж рідкісний парк, який навіть узимку, під снігом, залишає сильне південне враження - стільки в ньому вічнозеленого» (Андрухович, 1999: 32) (експліцитне градуювання /А>Б/);

«I конкретний Львів, і місто як таке, і Місто як абстракція. Місто взагалі〉 (Андрухович, 1999: 42 (імпліцитне градуювання / Львів - мало, Місто-абстракція - багато/).

2. Кон'юктивна градація (через кольороназви). Цей тип психологічної градації використовує перехід кольорової гами від білого до чорного або базується на трьох основних кольорах червоному, зеленому i синьому - це найдавніші терміни, які знаходимо на найвищому ступені узагальнення, напр.: «Старовинна вілла, початок століття, баварсько-карпатський стиль, вкрита рудою черепицею, стіни з частково білого каменю, з частково чорного дерева, декілька ганочків» (Андрухович, 1999: 32); «Не буде, не буде... (Буде!) Цих чорних - щзо ружі - стріч. Лиш очі як пройди - блудять По вигону білих пліч» (Матіос, 2007: 147).

Подальший розвиток кольорових систем відбувається кількома шляхами: а) уточненням відтінку через вживання градатора, який указує на світліший/темніший тон або яскравість тону; б) уточненням проміжного відтінку шляхом комбінації двох або трьох кольорових термінів; в) зіставленням терміна 3 предметом «еталоном» (цей тип найпродуктивніший); г) подальший розвиток «опредмеченої» кольороназви як самостійного кольороутворення наприклад, колір сепії - блідо-коричневий колір (проте не кожен такий колір може бути зіставлений із лексемою сепія, у чому полягає психологічність градаційних кольороназв). Напр.: «Був, власне, ніякий, як родова іпостась людини з анатомічного атласу, i вбраний у щзось таке ж неприкметне - блякле, кольору сепії: випаленого cmeny, сухої трави» (Забужко, 2004: 169). 
Вибір форми мовленнєвого втілення градаційної категорії, пов'язаної 3 категорією кількості, здійснюється автором комунікативного акту та підпорядковується певним психологічним закономірностям, загальним для людської мови. Правомірність застосування вказаних психологічних параметрів до лінгвістичного аналізу підтверджена висновком щодо збігу вербальних і образних семантичних структур на рівні глибинної семантики (Петренко, 1988: 82). Цей рівень виділяє В.Ф. Петренко серед інших рівнів «категоризації», що тлумачаться як «власне функціональні» утворення, які переходять одне в інше та визначаються характером, ступенем узагальнення ознак, на основі яких відбувається категоризація (Петренко, 1988).

Для змістової сфери приблизно-оцінної градації можна застосувати ще одне положення психосемантики: «Об’ єкти (поняття), які входять до різних семантичних класів на понятійному... рівні свідомості і мають подібне емоційне та образне забарвлення, на глибинному рівні категоризації стають конотативними синонімами чи антонімами та створюють синкретичні узагальнення» (Петренко,1988: 73).

Якщо розповсюдити поняття «синкретичне узагальнення» на мовленнєве мислення індивіда, в тому числі - на сферу градації, це чітко і просто пояснить суміщення в ядерних (для нематематичної сфери) градаційних словах «багато»/«мало» майже всіх можливих дискретних і безперервних, екстенсивних та інтенсивних кількісноградаційних значень «багато людей, питань, знань, пшениці; багато сміятися, читати, вчитися...».

Уважаємо, що саме цей рівень категоризації відповідає галузі мовних понятійних категорій. Очевидно, що мовна категорія градації безпосередньо входить до числа універсальних понятійних категорій і може бути розглянута як одна із предметних сфер цього рівня категоризації.

Таким чином, експериментальні методи семантики дозволяють установити залежність актуальних словесних значень від індивідуальної системи значень, до якої входять понятійні та образні компоненти, які можуть змінюватися залежно від завдання, яке стоїть перед суб'єктом висловлення, від мети висловлення, що вимагає певної глибини проникнення в зміст i свідомість, від емоційного стану суб'єкта, який впливає на 
характер категоризації, від словесного матеріалу, який вербалізує мовленнєвомисленнєву діяльність.

Наведений перелік може бути підставою для прагматичної інтерпретації висловлення щодо референції мовця та її залежності від авторських інтенцій.

Також він дає можливість тлумачити співвідношення індивідуального й соціального в тексті як використання (в міру когнітивної і мовної компетенції його автора та мети тексту) готових лексичних одиниць мови, які мають соціальну та етнічну нормованість та опираються на суспільні норми та практику.

Вивчення категорії градації пов'язане 3 дослідженням прагматичної категорії адресата, для якої можна застосувати такі психологічні постулати: «Під час побудови власних висловлювань кожна людина намагається враховувати, наприклад, погляди, переконання, симпатії та антипатії своїх слухачів» (Давыдов, 1986: 35).

Також, для мовленнєвого вираження градаційних характеристик реальних об'єктів варто додати фонд енциклопедичних знань адресата щодо відбиття градації, оскільки мовна семантика $\epsilon$ конгломератом різноманітних форм i засобів пізнавального відображення світу, від найпростіших структур нерозчленованого типу, синкретичних структур, через конкретно-образні уявлення i різні поняття та псевдопоняття до диференційованих наукових понять найвищого рівня абстракції.

\section{Висновки}

Отже, вибір форми мовленнєвого втілення категорії градації здійснюється автором комунікативного акту, підпорядковується певним психологічним закономірностям, загальним для людської мови. Правомірність перенесення психологічних параметрів у лінгвістичний аналіз підтверджується висновками щодо функціонування вербальних i образних семантичних структур на рівні глибинної семантики. Специфічні комунікативні одиниці висловлення, які використовуються авторами в текстах, мають широкий діапазон виражальних можливостей. Використання цих одиниць дозволяє авторам художніх творів досягати різнопланових 
стилістичних ефектів: вносити до написаного відчутний заряд розмовної експресії (ефект колоквіалізації); посилювати психологізм відображення внутрішнього стану персонажа (ефект психологізації); створювати підтекстове значення різної глибини інтенсивності (ефект імплікації); посилювати експресивну наповненість контексту. Також можливе вживання додаткових семантичних компонентів, які вказують на величину вияву ознаки та суб’єктивне ставлення автора до градаційної інформації.

Градаційно-оцінні структури є маніфестаціями синкретичних утворень, які опираються на глобальне порівняння при цілісному сприйнятті об'єкта з просторовими, часовими, тотальнопартитативними та іншими відношеннями.

Для повного аналізу та виявлення мовленнєвих репрезентантів категорії градації необхідна когнітивно-прагматична інтерпретація висловлень 3 градаційними компонентами та градаційних висловлень з фондом знань мовця (автора тексту), мотиваційними потребами, емоціями тощо. Базу для такої інтерпретації складають перераховані когнітивно-психологічні та соціальні аспекти мовної семантики.

\section{Література}

Андрухович, Ю. (1999). Дезорієнтація на місиевості: Спроби. Івано-Франківськ: «Лілея - НВ».

Баранов, В. (2013). Смерть по-білому. Київ: Ярославів Вал.

Выготский, Л.С. (1982). Мышление и речь (Т. 1-2). (Т. 2, с. 162-168). Москва: Педагогика.

Вольф, Е.М. (2002). Функциональная семантика оценки (2-е изд., доп.). Москва: Едиториал УРСС.

Гуцало, Є.П. (2007). Ментальність орди. Київ: Вид. дім «КМ Академія».

Давыдов, В.В. (1986). Проблемы развивающего обучения. Москва: Педагогика.

Журавлев, И.В., \& Журавлева, Ю.В. (2017). К построению коммуникативной модели речевого процесса: методологические проблемы. Bonpocbl психолингвистики, 3(33), 48-61.

Забужко, О. (2004). Сестро, сестро: Повісті та оповідання. Київ: Факт.

Засєкін, С., \& Розенгарт, Ю. (2018). Психолінгвістичні комп'ютерні інструменти лінгвістичного та перекладознавчого аналізу дискурсу. Psycholinguistics. Психолінгвістика. Психолингвистика, 23(2), 94-106. https://oi.org/10.5281/ zenodo. 1204994

Кацнельсон, С.Д. (1972). Типология языка и речевое мышиление. Ленинград: Наука. Кокотюха, А. (2006). Темна вода. Київ: Нора-друк. 
Психолінгвістичні передумови функиіювання градащії..

Марчук, Л. (2007). Функиіонально-семантичний аспект градації в українській мові. Кам'янець-Подільський: Аксіома.

Матіос, М. (2007). Жіночий аркан у саду нетерпіння: поезї. Львів: Піраміда.

Мушкетик, Ю. (2003). Хто і як виграв другу світову війну. Неопалима купина, 2, 48.

Петренко, В.Ф. (1988). Психосемантика сознания. Москва: Изд-во МГУ.

Пиаже, Ж. (1969). Избранныле психологические труды. Психология интеллекта. Генезис числа у ребенка. Логика и психология. Москва: Просвещение.

Процюк, С. (2004). Тотем. Кур'єр Кривбасу, 17, 34-95.

Рарицький, О. (2018). Володимир Свідзінський i шістдесятники: контексти осягання проблеми. Слово і час, 10, 34-47.

Таран, Л. (2007). Оповідання. Новочасна література, 1, 130-230.

Хьелл, Л., \& Зиглер, Д. (2000). Теории личности. Санкт-Петербург; Москва; Харьков; Минск: [б.м.].

Цінцірук, А. (2017). Коло Елу. Харків: Клуб сімейного дозвілля.

Juhasz, B.J., Lai, Y.-H., \& Woodcock, M.L. (2015). A database of 629 English compound words: ratings of familiarity, lexeme meaning dominance, semantic transparency, age of acquisition, imageability, and sensory experience. Behavior Research Methods, 47(4), 1004-1019. https://doi.org/10.3758/s13428-014-0523-6

Keuleers, E., \& Balota, D.A. (2015). Megastudies, crowdsourcing, and large datasets in psycholinguis-tics: An overview of recent developments. Journal of Experimental Psychology, 68(8), 1457-1468. https://doi.org/10.1080/17470218.2015.1051065

Maslow, A.H. (1971). Toward a humanistic biology. American Psychologist, 24, 724 735. https://doi.org/10.1037/h0027859

Neuman, Yalr, Neuman, Yiftach, \& Cohen, Yochai. (2017). A Novel Procedure for Measuring Semantic Synergy. Journal Complexity, 14, 8. https://doi. org/10.1155/2017/5785617

Turney, P.D., \& Pantel, P. (2010). From frequency to meaning: vector space models of semantics. Journal of Artificial Intelligence Research, 37, 141-188. https://doi. org/10.1613/jair.2934

Andrews, M., Vigliocco, G., \& Vinson, D. (2009). Integrating experiential and distributional data to learn semantic representations. Psychological Review, 116(3), 463-498. https://doi.org/10.1037/a0016261

\section{References}

Andrukhovych, Yu. (1999). Dezoriientatsiia na mistsevosti: Sproby [Disorientation on the place: Attempts]. Ivano-Frankivsk: «Lileia - NV» [in Ukrainian].

Baranov, V. (2013). Smert po-bilomu [Death in white colour]. Kyiv: Yaroslaviv Val [in Ukrainian].

Vygotskiy, L.S. (1982). Myshleniye i rech [Thinking and speech] (Vols. 1-2), (Vols. 2, pp. 162-168). Moscow: Pedagogika [in Russian].

Volf, Ye.M. (2002). Funktsionalnaya semantika otsenki [Functional semantics of assessment] (2nd ed., rev.). Moscow: Editorial URSS [in Russian].

Hutsalo, Ye.P. (2007). Mentalnist ordy [Horde mentality]. Kyiv: Vyd. Dim «KM Academiia» [in Ukrainian].

Davydov, V.V. (1986). Problemy razvivayushchego obucheniya [Problems of developmental learning]. Moscow: Pedagogy [in Russian]. 
Zhuravlev, Y.V., \& Zhuravleva, Yu.V. (2017). K postroenyiu kommunykatyvnoi modely rechevoho protsessa: metodolohycheskye problemы [Building a communicative Model of Verbal Process: Methodological Problems]. Voprosy psykholynhvystyky Journal of Psycholinguistics, 3(33), 48-61 [in Russian].

Zabuzhko, O. (2004). Sestro, sestro: Povisti ta opovidannia [Sister, sister: Narratives and short stories]. Kyiv: Fakt [in Ukrainain].

Zasiekin, S., \& Rozenhart, Yu. (2018). Psykholinhvistychni kompiuterni instrumenty linhvistychnoho ta perekladoznavchoho analizu dyskursu [Psycholinguistic Computerized Tools of Linguistic and Translation Studies Discourse Analysis]. Psykholinhvistyka - Psycholinguistics, 23(2), 94-106. https://doi.org/10.5281/ zenodo.1204994 [in Ukrainian].

Katsnel'son, S.D. (1972). Tipologiya yazyka I rechevoye myshleniye [Typology of language and speech thinking]. Leningrad: Nauka [in Russian].

Kokotyukha, A. (2006). Temna voda [Dark water]. Kyiv: Nora-press [in Ukrainain].

Marchuk, L. (2007). Funktsionalno-semantychnyi aspekt hradatsii v ukrainskii movi [The functional and semantic aspect of gradation in the Ukrainian]. KamianetsPodilskyi: Aksioma [in Ukrainain].

Matios, M. (2007). Zhinochyi arkan u sadu neterpinnia: poezii [Woman lasso in the garden of impatience: poetry]. Lviv: Piramida [in Ukrainian].

Mushketyk, Yu. (2003). Khto i yak vyhrav druhu svitovu viinu [Who and when won the Second World War]. Neopalyma kupyna - Unburnt tussok, 2, 48 [in Ukrainian].

Petrenko, V.F. (1988). Psihosemantika soznaniya [Psychosemantics of consciousness]. Moscow: Izd-vo MGU [in Russian].

Piazhe, Zh. (1969). Izbrannyye psichologicheskiye trudy. Psikhologiya intellekta. Genesis chisla u rebenka. Logika ipsikhologiya [Selected psychological works. Psychology of the intellect. The genesis of the number of the child. Logic and psychology]. Moscow: Prosveshcheniye [in Russian].

Protsiuk, S. (2004). Totem [Totem]. Kurier Kryvbasu - The courier of Kryvbas, 17, 34-95 [in Ukrainian].

Rarytskyi, O. (2018). Volodymyr Svidzinskyi i shistdesiatnyky: konteksty osiahannia problemy [Volodymyr Svidzinskyi and the sixties: the context of understanding the problem]. Slovo $i$ chas - The Word and time, 10, 34-47 [in Ukrainain].

Taran, L.O. (2007). Opovidannia [Short stories]. Novochasna literature - Modern literature, 1, 130-230 [in Ukrainian].

Hjelle, L., \& Ziegler, D. (2000). Teorii lichnosti [Personality theories]. Saint Petersburg; Moscow; Kharkov; Minsk: [b.m.] [in Russian].

Tsintsiruk, A. (2017). Kolo Elu [Near Ell]. Kharkiv: Klub simeinoho dozvillia [in Ukrainian].

Juhasz, B.J., Lai, Y.-H., \& Woodcock, M.L. (2015). A database of 629 English compound words: ratings of familiarity, lexeme meaning dominance, semantic transparency, age of acquisition, imageability, and sensory experience. Behavior Research Methods, 47(4), 1004-1019. https://doi.org/10.3758/s13428-014-0523-6

Keuleers, E., \& Balota, D.A. (2015). Megastudies, crowdsourcing, and large datasets in psycholinguis-tics: An overview of recent developments. Journal of Experimental Psychology, 68(8), 1457-1468. https://doi.org/10.1080/17470218.2015.1051065

Maslow, A.H. (1971). Toward a humanistic biology. American Psychologist, 24, 724735. https://doi.org/10.1037/h0027859 
Психолінгвістичні передумови функиіювання градащії..

Neuman, Yalr, Neuman, Yiftach, \& Cohen, Yochai. (2017). A Novel Procedure for Measuring Semantic Synergy. Journal Complexity, 14, 8. https://doi. org/10.1155/2017/5785617

Turney, P.D., \& Pantel, P. (2010). From frequency to meaning: vector space models of semantics. Journal of Artificial Intelligence Research, 37, 141-188. https://doi. org/10.1613/jair.2934

Andrews, M., Vigliocco, G., \& Vinson, D. (2009). Integrating experiential and distributional data to learn semantic representations. Psychological Review, 116(3), 463-498. https://doi.org/10.1037/a0016261

\section{АНОТАЦІЯ}

Мета дослідження. Описати об'єктивні та суб'єктивні чинники мовної семантичної інтерпретації мисленнєвого змісту градації (психологічний $i$ лінгвістичний аспекти в семантиці градації).

Методики дослідження. У статті описано підстави виокремлення в українській мові функційно-семантичної категорії градації, яка має вияв в одиницях різних рівнів. у межах цих понять доведено лінгвокогнітивний характер дослідження, оскільки одним із завдань роботи є встановлення ментальноантропоцентричних та психолінгвістичних чинників появи градаційних висловлень в українській мові, які демонструють єдність лінгвістики і психології, мови і мислення. Методика полягала у порівнянні матеріалів різного ступеня градації, проведенні гіпотетичного моделювання градаційної шкали на основі функціонування вербальних маркерів градації, визначенні психолінгвістичних підстав для функціювання градації в індивідуальній картині світу. Взаємодія об'єктивного (концептуальний світ градуйованого О) та суб'єктивного (емоційна й інтелектуальна сфера градатора S) світів створює градаційний фрагмент у мові, його орієнтацію щодо градаційного виміру (О об'єкт, S- суб'єкт градації).

Результати. Дослідження мотивації, семантичної акцентуації та характеру комунікантів, тобто внутрішнього світу мовця і слухача, автора тексту $і$ читача дозволило кодувати та декодувати інформацію, подану в тексті. Для декодування нами ідентифріковано одиниці градації та експліковано їх на рівні речення (тексту), виділено прагматичні структури з надмірною інформацією. Таким чином, частково розв'язана проблема певних стереотипів як норми сприйняття довкілля, відхилення від норми та розширено можливості реконструкції якісної характеристики мовної картини світу.

Висновки. Вибір форми вербального втілення категорії градації здійснюється автором комунікативного акту, підпорядковується певним психологічним закономірностям, загальним для людської мови, але ментально-індивідуальним щодо особистості комуніканта та індивідуальної мовної картини світу.

Ключові слова: категорія градації, градаційна лексема, інтроверт, екстраверт, персонологія, імплікація. 
Psycholinguistic Preconditions of Gradation Functioning...

Марчук Людмила, Рарицкий Олег. Психолингвистические предисловия функционирования градации в индивидуальной картине мира

\section{АННОТАЦИЯ}

Цель исследования. Описать объективные и субъективные факторы языковой семантической интерпретации смыслового содержания градации (психологический и лингвистический аспекты в семантике градации).

Методики исследования. В статье описываем функционально-семантическую категорию градации, которая вербально проявляется в единицах разного уровня. В рамках этих понятий обосновываем когнитивный характер исследования, поскольку одной из задач работы является определение ментально-антропоцентрических и психолингвистических факторов появления градационных высказываний в украинском языке, которые демонстрируют единство лингвистики и психологии, языка и мышления. Методика состояла из сравнения материалов разной степени градации, проведении гипотетического моделирования градуальной шкалы через функционирование вербальных маркеров градации, определении психолингвистических причин для функционирования градации в индивидуальной картине мира. Взаимодействие объективного (концептуальный мир градуированного О) и субъективного (эмоциональная и интеллектуальная сорера градатора S) миров создает градационный фрагмент в языке, его ориентацию по отношению $к$ градационному измерению (O - объект, $S$ - субъект градации).

Результаты. Исследование мотивации, семантической акцентуации и характера коммуникантов, т.е. внутреннего мира адресата и адресанта, автора текста и читателя, разрешило кодировать и декодировать информацию, представленной в тексте. Для декодирования нами произведена идентификация единиц градации и экспликация их на уровне предложения (текста), выделены прагматические структуры с избыточной информацией. Таким образом, частично решена проблема определенных стереотипов как нормы восприятия окружающей среды, отклонения от нормы и расширены возможности реконструкции качественной характеристики языковой картины мира.

Выводы. Выбор формы вербального воплощения категории градации осуществляется автором коммуникативного акта, подчиняется определенным психологическим закономерностям, общим для человеческого языка, но ментально-индивидуальным по отношению к личности коммуниканта и индивидуальной языковой картины мира.

Ключевые слова: категория градации, градационная лексема, интроверт, экстраверт, персонология, импликация. 